\title{
Case Series: Deep Brain Stimulation in Patients with FXTAS
}

\section{Randi J Hagerman ${ }^{1,2}$, Jamie S Pak ${ }^{3}$, Melina Ortigas ${ }^{1}$, John Olichney ${ }^{4}$, Robert Frysinger ${ }^{5}$, Madeline Harrison ${ }^{6}$, Edmund Cornman ${ }^{7}$, Danuta Z.} Loesch $^{8}$, Richard G Bittar ${ }^{9}$, Richard Peppard ${ }^{10}$, Lin Zhang ${ }^{4 *}$ and Kiarash Shahlaie ${ }^{11}$

${ }^{1}$ Department of Pediatrics, M.I.N.D. Institute, School of Medicine, University of California, Davis, Sacramento, CA, USA

${ }^{2}$ Department of Pediatrics, School of Medicine, University of California, Davis, Sacramento, CA, USA

${ }^{3}$ Mount Sinai School of Medicine, Department of Dermatology, Mount Sinai Medical Center, New York, NY, USA

${ }^{4}$ Department of Neurology, School of Medicine, University of California, Davis, Sacramento, CA, USA

${ }^{5}$ Department of Neurological Surgery, University of Virginia School of Medicine, Charlottesville, VA, USA

${ }^{6}$ Department of Neurology, University of Virginia School of Medicine, Charlottesville, VA, USA

${ }^{7}$ Department of Sleep Medicine and Neurology, Sleep Disorders Center of Virginia, Midlothian, VA, USA

${ }^{8}$ Department of Psychology, School of Psychological Science, La Trobe University, Melbourne, VIC, Australia

${ }^{9}$ Department of Neurological Surgery, Precision Neurosurgery, Melbourne, Australia

${ }^{10}$ Department of Neurology, St. Vincent's Hospital, Carlton, VIC, Australia

${ }^{11}$ Department of Neurological Surgery, School of Medicine, University of California, Davis, Sacramento, CA, USA

\begin{abstract}
Objective: We describe 3 carriers of the FMR1 premutation with the Fragile X-associated Tremor Ataxia Syndrome (FXTAS) whose tremor was significantly improved by bilateral Deep Brain Stimulation (DBS) to Ventral Intermediate
\end{abstract} nucleus (Vim) of the thalamus.

Background: FXTAS is a recently described neurodegenerative disorder caused by CGG expansions of the FMR1 gene within the premutation range (55 to 200 CGG repeats). Individuals with FXTAS typically develop an intention tremor followed by gait ataxia within two years. Vim DBS has been shown to effectively treat tremor in a variety of disorders, including Parkinson's disease and essential tremor.

Design/Methods/Results: Three men ages 62, 59 and 70 with FXTAS were treated surgically with bilateral Vim DBS. All patients experienced a significantly beneficial effect on tremor. Ataxia improved in case 1 and temporarily in case 2, but worsened in case 3 . All patients experienced mild worsening of dysarthria, although the patients and their families unanimously felt there was a worthwhile benefit overall.

Conclusions: These cases provided first hand evidence that bilateral Vim DBS effectively manages tremor in selected patients with FXTAS. DBS may prove to be a viable therapeutic option for treating tremor and/or ataxia with or without other medical therapeutics in patients with FXTAS.

Keywords: Deep Brain Stimulation (DBS); FXTAS; Tremor; Ataxia; Surgery

\section{Introduction}

The Fragile X-associated Tremor Ataxia Syndrome (FXTAS) is a neurodegenerative disorder first described in 2001 [1]. It is caused by the premutation (55 to 200 CGG repeats) in the 5' untranslated region of the FMR1 gene at Xq27.3. The premutation is associated with an elevation of FMR1-mRNA (2 to 8 times normal levels) [2], which lead to RNA gain-of-function. These symptoms typically begin in the early 60 s in premutation carriers and FXTAS affects approximately $40 \%$ of male carriers [3] and 8 to $16 \%$ of female carriers [4,5].

Individuals with FXTAS usually present with an intention tremor followed by gait ataxia within a year or two [6]. In addition, patients often present with neuropathy associated with pain in the lower extremities; autonomic dysfunction including hyper- or hypotension, urinary incontinence, fainting spells and impotence; parkinsonism with mixed type tremors, rigidity and bradykinesia; and cognitive impairment affecting memory and executive function $[1,7,8]$.

The MRI of patients with FXTAS typically demonstrates brain atrophy and white matter hyperintensities, with $60 \%$ of males and $13 \%$ of females showing involvement of the middle cerebellar peduncles [9]. Neuropathology demonstrates eosinophilic intranuclear inclusions in neurons and astrocytes throughout the brain with the highest counts in the hippocampus and certain areas of the limbic system [10]. Inclusions can also occur in the peripheral nervous system [11] and other organs including the thyroid, adrenal gland and the Leydig cells of the testicles [12].
Even though FXTAS has been well defined in terms of its clinical presentation, neuroimaging and pathology, its targeted therapeutic options have been sparse. Furthermore, the diverse spectrum of its clinical presentation encourages clinical uncertainty, leading to potential misdiagnoses. These misdiagnoses include Parkinson's Disease (PD), sporadic cerebellar ataxia and Essential Tremor (ET) [13]. Previous surgical intervention from our collaborators [14-18] represents the first attempt at applying Deep Brain Stimulation (DBS) to manage FXTAS cases and underscores the importance of the syndromic recognition and need for experimental therapeutics.

DBS is a neurosurgical procedure that implants a brain pacemaker device to deliver constant electrical stimulation to specific targets in the brain. Leads are placed in different areas of the brain according to the symptoms involved. DBS of the subthalamic nucleus or of the internal segment of globus pallidus has been shown to significantly

*Corresponding author: Lin Zhang, MD, PhD, Lawrence J. Ellison Ambulatory Care Center, 4860 Y St, Suite 0100, Sacramento, CA, USA, 95817, Tel: (916) 7343588; E-mail: lin.zhang@ucdmc.ucdavis.edu

Received June 05, 2012; Accepted August 03, 2012; Published August 05, 2012

Citation: Hagerman RJ, Pak JS, Ortigas M, Olichney J, Frysinger R, et al. (2012) Case Series: Deep Brain Stimulation in Patients with FXTAS. Brain Disord Ther 1:104. doi:10.4172/2168-975X.1000104

Copyright: (c) 2012 Hagerman RJ, et al. This is an open-access article distributed under the terms of the Creative Commons Attribution License, which permits unrestricted use, distribution, and reproduction in any medium, provided the original author and source are credited. 
improve motor complications in severe PD [19], while DBS of the Ventral intermediate (Vim) thalamic nucleus has been shown to reduce tremors in PD and non-Parkinsonian ET [20]. However, a previous attempt at targeting the Vim nucleus bilaterally to treat FXTAS was ineffective because of a lead fracture and suboptimal placement of electrodes [14]. In another case, a positive response to bilateral thalamic stimulation led to a marked reduction of tremor in a 60 year-old male with FXTAS, though gait ataxia persisted [15]. A third case of bilateral thalamic stimulation yielded moderate to marked tremor suppression, worsening of gait and speech that was neither improved nor worsened by DBS deactivation for 18 hours, and a continuing decline in cognition [16]. Here we report 3 new male FXTAS cases of bilateral Vim DBS and their postoperative details.

All three cases were first assessed as clinical patients at their respective neurology clinics. Their initial clinical diagnoses were established according to international diagnostic criteria. The diagnoses of FXTAS were confirmed only after genetic testing for CGG repeats in the FMR1 gene was performed.

1. Cases 1 and 2 signed informed consent at University of California, Davis and Case 3 signed informed consent from LaTrobe University.

\section{Case Description}

\section{Case 1}

This is a 62 -year-old minister who carries the premutation with 85 CGG repeats. His neurological symptoms began at age 52 when he had a stroke that involved the internal capsule and the hypothalamus. He had sudden onset of numbness and subsequent weakness involving his right arm and leg. After 10 days of hospitalization and subsequent rehabilitation, these symptoms resolved. Three months later, however, his wife noticed a tremor in his right hand when he held the Bible. His right hand tremor gradually worsened and eventually involved both hands with interference in daily living activities, including eating and dressing. At age 53, he developed an unsteady walking with tendency of falling. He then developed restless leg syndrome, memory difficulties and sleep apnea that responded first to CPAP and then to BI-PAP. Because of his inability to do the activities that he enjoyed, he developed depression and received sertraline treatment with a good response.

On his neurological examination, he had an intact cognition and normal cranial nerves. He had a prominent course intention tremor that was both postural and action. He did not have rest tremor or rigidity. He had ataxia of cerebellar type and was unable to tandem.

Based on this 10-year history of progressive tremor and balance difficulties, the patient was initially diagnosed with ET by his private neurologist and at age 60 , he was implanted with bilateral thalamic Vim DBS according to the standard surgical protocol.

Preoperative neuropsychological testing demonstrated a verbal IQ of 124, Performance IQ of 102 and a Full Scale IQ of 115 on the Wechsler Adult Intelligence Scales III (WAIS-III). His Perceptual organization and working memory were in the $68^{\text {th }}$ and $66^{\text {th }}$ percentiles respectively while his verbal comprehension fell in the $98^{\text {th }}$ percentile. His processing speed was most impaired, falling in the $14^{\text {th }}$ percentile. In the Wechsler Memory Scales III (WMS-III), the patient scored in the $99^{\text {th }}$ percentile for auditory immediate, auditory delayed and auditory recognition-delayed primary indexes but his working memory fell in the $21^{\text {st }}$ percentile.

DBS electrodes were implanted under local anesthesia using a Leksell model G stereotactic frame. Volumetric T1-weighted MR series were taken with fiducial plates in place. Medtronic model 3387 electrodes were advanced to target, left side first through the burr holes placed about $3 \mathrm{~cm}$ lateral to midline just anterior to the coronal suture. Monopolar macrostimulation was performed with a Medtronic 3625 test stimulator. Stimulation at $130 \mathrm{~Hz}$ and 60 microseconds produced good tremor control at deeper contacts at amplitudes of 2 to 3.5 volts with transient paresthesias at higher amplitudes. The tips of the leads were left at VIM of the thalamus. A post-operative MR series was taken about 12 hours after the implant operation to confirm placement and rule out hemorrhagic complications. A Medtronic Kinetra Implantable Pulse Generator (IPG) was implanted under general anesthesia in a separate procedure several weeks after the electrode implantation. Stimulation was initiated about one week afterwards.

Following his DBS procedure, the patient's intention tremor was significantly improved and his ataxia also improved, but his speech was slightly more slurred when the DBS was turned on and left at 3 volts, 60 microseconds, and $130 \mathrm{~Hz}$ for amplitude, pulse width, and frequency, respectively. At age 61, the diagnosis of FXTAS was established corroborated with the finding of scattered white matter hyperintensities that included the middle cerebellar peduncles (MCP sign) on his MRI. His MRI also demonstrated mild volume loss in the cerebrum and evidence of a lacunar infarct in the left superior aspect of the thalamus.

During his FXTAS study visit two years after his Vim DBS, his blood pressure was $155 / 76$, heart rate was 57 , height was 179 centimeters, and weight was 98.8 kilograms. The quantitative improvements of his tremor with the DBS on vs. off were measured with the CATSYS, an instrument previously described to document tremor severity in FXTAS [21] (Table 1). He demonstrated a coarse intention tremor on finger-to-nose testing in addition to a coarse postural tremor, which improved markedly when the DBS was turned on. He did not have a resting tremor but he did have mild rigidity on the right. He was unable to tandem walk with the DBS turned off, but was able to tandem when his stimulator was turned back on (Table 1).

\section{Case 2}

Case 2 is a 59 -year-old male with 154 CGG repeats. He had 12 years of education and currently works for the government in a job training position. His birth and early childhood history were normal. At about 49 , one year after his divorce, he developed a "no-no" type head tremor that has been present ever since. When he was 51, he developed an intention tremor in his right hand that gradually progressed to interfere with daily tasks such as buttoning his shirt, eating and handwriting. Approximately 3 years later, his left hand also began exhibiting tremors. He started to receive botulinum toxin (Botox) injections in the cervical region at age 57 . These have been helpful for his tremor and the benefits last about four months after the injection. Botox was also tried on his right arm, but was discontinued later due to prolonged weakness of the injected arm. Occasionally, he has tingling and numbness in his upper right leg and lower left leg. This has been intermittent for the past 10 years. He has had three episodes of non-orthostatic hypotension in the past.

On examination, his vitals were normal. His motor strength was full throughout. His deep tendon reflexes were hyporeflexic on upper and lower extremities except that they were absent on his right ankle. He had a significant intention tremor in both hands. Periodically, he had a resting tremor on both hands. He had mild unsteadiness initially while tandem walking, but subsequently took six steps without difficulty. 
Citation: Hagerman RJ, Pak JS, Ortigas M, Olichney J, Frysinger R, et al. (2012) Case Series: Deep Brain Stimulation in Patients with FXTAS. Brain Disord Ther 1:104. doi:10.4172/2168-975X.1000104

Page 3 of 6

\begin{tabular}{|c|c|c|c|c|c|c|c|c|c|}
\hline Subject ID & Age & Sex & $\begin{array}{l}\text { CGG } \\
\text { Repeats }\end{array}$ & Family History & $\begin{array}{l}\text { Preop Clinical } \\
\text { Presentation }\end{array}$ & DBS Type & $\begin{array}{l}\text { Optimal DBS } \\
\text { Settings }\end{array}$ & Postop Clinical Presentation & Comments \\
\hline Case 1 & 62 & M & 85 & $\begin{array}{l}\text { FXS carrier in one } \\
\text { daughter }\end{array}$ & $\begin{array}{l}\text { Postural and action } \\
\text { tremor. No rest tremor } \\
\text { or rigidity. Frequent } \\
\text { falling episodes, gait } \\
\text { ataxia. }\end{array}$ & $\begin{array}{l}\text { Bilateral Vim } \\
\text { Thalamus }\end{array}$ & $\begin{array}{l}3.0 \mathrm{~V} \\
130 \mathrm{~Hz} \\
60 \mu \mathrm{sec}\end{array}$ & $\begin{array}{l}\text { Intention tremor significantly } \\
\text { improved. Ataxia improved. } \\
\text { Speech slightly more slurred. }\end{array}$ & See Discussion \\
\hline Case 2 & 59 & M & 154 & $\begin{array}{l}\text { No tremor or any } \\
\text { other movement } \\
\text { disorders }\end{array}$ & $\begin{array}{l}\text { Significant intention } \\
\text { tremor, periodic resting } \\
\text { tremor in both hands. } \\
\text { Mild unsteadiness with } \\
\text { tandem gait. }\end{array}$ & $\begin{array}{l}\text { Bilateral Vim } \\
\text { Thalamus }\end{array}$ & & $\begin{array}{l}\text { Tremor in both hands } \\
\text { improved. Ataxia temporarily } \\
\text { improved after surgery. }\end{array}$ & See Discussion \\
\hline Case 3 & 70 & M & 86 & $\begin{array}{l}\text { No tremor or any } \\
\text { other movement } \\
\text { disorders }\end{array}$ & $\begin{array}{l}\text { Postural, action, } \\
\text { and rest tremor in } \\
\text { extremities, head, and } \\
\text { neck. Gait ataxia with } \\
\text { inability to tandem walk. }\end{array}$ & $\begin{array}{l}\text { Bilateral Vim } \\
\text { Thalamus }\end{array}$ & $\begin{array}{l}2.0-3.8 \mathrm{~mA} \\
130 \mathrm{~Hz} \\
90 \mu \mathrm{sec}\end{array}$ & $\begin{array}{l}\text { Dramatic improvement in } \\
\text { tremor, but deterioration in } \\
\text { gait. Speech and memory } \\
\text { deteriorated. }\end{array}$ & See Discussion \\
\hline $\begin{array}{l}\text { Leehey, et } \\
\text { al. [14] }\end{array}$ & 63 & M & 160 & $\begin{array}{l}\text { Mother, brother } \\
\text { dx ET }\end{array}$ & $\begin{array}{l}\text { Postural and action } \\
\text { tremor in all extremities, } \\
\text { head tremor. Marked } \\
\text { instability in tandem } \\
\text { gait. }\end{array}$ & $\begin{array}{l}\text { Bilateral Vim } \\
\text { Thalamus }\end{array}$ & N/A & $\begin{array}{l}\text { Limb tremor completely } \\
\text { resolved "due to a profound } \\
\text { "microthalamotomy' effect." } \\
\text { Decreased head tremor. } \\
\text { Worsened balance, slower } \\
\text { speech. }\end{array}$ & $\begin{array}{l}\text { DBS not turned } \\
\text { on due to } \\
\text { "microthalamotomy" } \\
\text { effect. ET dx at } \\
49 \text { yo. }\end{array}$ \\
\hline $\begin{array}{l}\text { Peters, et } \\
\text { al. [15] }\end{array}$ & 60 & M & 112 & $\begin{array}{l}\text { Mother, } \\
\text { grandmother with } \\
\text { tremor. Two aunts } \\
\text { and one uncle with } \\
\text { tremor, gait ataxia. } \\
\text { First cousin strongly } \\
\text { affected. }\end{array}$ & $\begin{array}{l}\text { Progressive bilateral } \\
\text { postural/action tremor } \\
\text { of hands/arms, postural } \\
\text { tremor both legs. } \\
\text { Slight head tremor. No } \\
\text { rest tremor in limbs. } \\
\text { Progressive gait ataxia. }\end{array}$ & $\begin{array}{l}\text { Bilateral Vim } \\
\text { Thalamus }\end{array}$ & & $\begin{array}{l}\text { Marked reduction of tremor. } \\
\text { Gait ataxia persisted. }\end{array}$ & Initial dx of ET. \\
\hline $\begin{array}{l}\text { Ferrara, et } \\
\text { al. [16] }\end{array}$ & 68 & M & 106 & $\begin{array}{l}\text { Brother with tremor. } \\
\text { Daughter with } \\
\text { premature ovarian } \\
\text { failure. }\end{array}$ & $\begin{array}{l}\text { Postural and intention } \\
\text { tremor of upper } \\
\text { extremities, severely } \\
\text { limiting hand function. } \\
\text { Gait ataxia. MMSE } 25 .\end{array}$ & $\begin{array}{l}\text { Bilateral Vim } \\
\text { Thalamus }\end{array}$ & $\begin{array}{l}4 / 4 \mathrm{~V} \\
160 / 185 \mathrm{~Hz} \\
90 / 90 \mu \mathrm{sec} \\
1 / 2\end{array}$ & $\begin{array}{l}\text { Moderate to marked tremor } \\
\text { suppression. Speech and gait } \\
\text { gradually worsened with no } \\
\text { effect of DBS deactivation for } \\
18 \text { hours. Cognition continued } \\
\text { to decline (MMSE 22). }\end{array}$ & \\
\hline $\begin{array}{l}\text { Xie, et al. } \\
{[17]}\end{array}$ & 65 & $M$ & 75 & $\begin{array}{l}\text { Brother with tremor. } \\
\text { Daughters with } \\
\text { FMR1 premutation } \\
\text { but asymptomatic. }\end{array}$ & $\begin{array}{l}\text { Severe postural, } \\
\text { kinetic, intention } \\
\text { tremors of upper } \\
\text { extremities (worse on } \\
\text { R). Mild resting tremor } \\
\text { of hands, jaw, tongue, } \\
\text { neck, moderate vocal } \\
\text { tremor. Broad gait with } \\
\text { difficulty in tandem. }\end{array}$ & $\begin{array}{l}\text { Unilateral L } \\
\text { Vim Thalamus }\end{array}$ & $\begin{array}{l}2.6 \mathrm{~V} \\
185 \mathrm{~Hz} \\
60 \mu \mathrm{sec} \\
1-\end{array}$ & $\begin{array}{l}\text { Significant improvement of } \\
\text { tremors. Improvements in daily } \\
\text { living function. No decline in } \\
\text { gait, speech, or cognition. }\end{array}$ & \\
\hline $\begin{array}{l}\text { Senova, et } \\
\text { al. [18] }\end{array}$ & 61 & N/A & 95 & $\begin{array}{l}\text { Sister and maternal } \\
\text { aunt with Tremor; } \\
\text { two nephews with } \\
\text { mental retardation. }\end{array}$ & $\begin{array}{l}\text { Postural and intentional } \\
\text { tremor in superior } \\
\text { limbs, dominant in } \\
\text { L, mainly proximal. } \\
\text { Cerebellar ataxia } \\
\text { present. }\end{array}$ & $\begin{array}{l}\text { Unilateral R } \\
\text { Vim Thalamus }\end{array}$ & $\begin{array}{l}2.5 \mathrm{~V} \\
130 \mathrm{~Hz} \\
60 \mu \mathrm{sec} \\
0-\end{array}$ & $\begin{array}{l}\text { Tremor reduced. Ataxia SARA } \\
\text { score } 30.2 \% \text { improvement at } \\
6 \text {-month follow-up. Cognition } \\
\text { and speech not affected. }\end{array}$ & \\
\hline
\end{tabular}

Table 1: Comparison of CATSYS Parameters of Case 1 with Stimulator On and Off.

Neuropsychological testing was performed preoperatively and revealed that his Verbal IQ was115, Performance IQ 99 and Full Scale IQ 108. The WMS revealed no memory impairment. His index scores for auditory immediate, auditory delayed and auditory recognitiondelayed all fell in the average range, while his working memory fell in the High average range.

Bilateral Vim DBS was carried out at age 59 years with a beneficial effect on his intention tremor. For surgical planning a T-2 weighted MRI scan was obtained under general anaesthesia prior to surgery. At surgery, the base ring of the Cosman-Roberts-Wells (CRW) frame was fitted to his skull under sedation and local anesthesia and a stereotactic CT scan performed. Using Image Fusion and Neurosight Arc, the trajectory that traversed the Vim and ended up with the tip touching Zona Incerta were calculated for both hemispheres. Through bilateral frontal scalp incisions and a $2.5 \mathrm{~mm}$ twist drill craniostomy, Medtronic 3387 electrodes were passed to target whilst examining the patient for the effects of stimulation by the examining neurologist. Total tremor suppression was obtained bilaterally, and the electrodes were plated to his skull and externalized. A check stereotactic CT scan confirmed accuracy of the final lead placement and the effects of stimulation were studied for a week. Having achieved an excellent response the following week under general anesthesia, a dual-channel Kinetra IPG were connected via two extension cables.

Tremor on his right hand was improved clinically when the stimulator was turned on. He is able to carry out his activities of daily living including using utensils, writing, and shaving. His left hand still has mild tremors, although much improved also. However, when the stimulation is increased in the attempt to improve his tremor on his left arm his speech slurs significantly, so the stimulation was kept at a lower range on this side. His ataxia was temporarily improved after surgery but the benefit did not sustain 6 months after his surgery. 
Citation: Hagerman RJ, Pak JS, Ortigas M, Olichney J, Frysinger R, et al. (2012) Case Series: Deep Brain Stimulation in Patients with FXTAS. Brain Disord Ther 1:104. doi:10.4172/2168-975X.1000104

Page 4 of 6

\begin{tabular}{|c|c|c|c|c|c|c|c|c|c|}
\hline Subject ID & Age & Sex & \begin{tabular}{l|} 
CGG \\
Repeats
\end{tabular} & Family History & $\begin{array}{l}\text { Preop Clinical } \\
\text { Presentation }\end{array}$ & DBS Type & $\begin{array}{l}\text { Optimal DBS } \\
\text { Settings }\end{array}$ & Postop Clinical Presentation & Comments \\
\hline Case 1 & 62 & M & 85 & $\begin{array}{l}\text { FXS carrier in one } \\
\text { daughter }\end{array}$ & $\begin{array}{l}\text { Postural and action } \\
\text { tremor. No rest tremor } \\
\text { or rigidity. Frequent } \\
\text { falling episodes, gait } \\
\text { ataxia. }\end{array}$ & $\begin{array}{l}\text { Bilateral Vim } \\
\text { Thalamus }\end{array}$ & $\begin{array}{l}3.0 \mathrm{~V} \\
130 \mathrm{~Hz} \\
60 \mu \mathrm{sec}\end{array}$ & $\begin{array}{l}\text { Intention tremor significantly } \\
\text { improved. Ataxia improved. } \\
\text { Speech slightly more slurred. }\end{array}$ & See Discussion \\
\hline Case 2 & 59 & $M$ & 154 & $\begin{array}{l}\text { No tremor or any } \\
\text { other movement } \\
\text { disorders }\end{array}$ & $\begin{array}{l}\text { Significant intention } \\
\text { tremor, periodic } \\
\text { resting tremor in } \\
\text { both hands. Mild } \\
\text { unsteadiness with } \\
\text { tandem gait. }\end{array}$ & $\begin{array}{l}\text { Bilateral Vim } \\
\text { Thalamus }\end{array}$ & & $\begin{array}{l}\text { Tremor in both hands improved. } \\
\text { Ataxia temporarily improved after } \\
\text { surgery. }\end{array}$ & See Discussion \\
\hline Case 3 & 70 & $M$ & 86 & $\begin{array}{l}\text { No tremor or any } \\
\text { other movement } \\
\text { disorders }\end{array}$ & $\begin{array}{l}\text { Postural, action, } \\
\text { and rest tremor in } \\
\text { extremities, head, and } \\
\text { neck. Gait ataxia with } \\
\text { inability to tandem } \\
\text { walk. }\end{array}$ & $\begin{array}{l}\text { Bilateral Vim } \\
\text { Thalamus } \\
\end{array}$ & $\begin{array}{l}2.0-3.8 \mathrm{~mA} \\
130 \mathrm{~Hz} \\
90 \mu \mathrm{sec}\end{array}$ & $\begin{array}{l}\text { Dramatic improvement in tremor, } \\
\text { but deterioration in gait. Speech } \\
\text { and memory deteriorated. }\end{array}$ & See Discussion \\
\hline $\begin{array}{l}\text { Leehey, et } \\
\text { al. [14] }\end{array}$ & 63 & $M$ & 160 & $\begin{array}{l}\text { Mother, brother } \\
\text { dx ET }\end{array}$ & $\begin{array}{l}\text { Postural and } \\
\text { action tremor in all } \\
\text { extremities, head } \\
\text { tremor. Marked } \\
\text { instability in tandem } \\
\text { gait. }\end{array}$ & $\begin{array}{l}\text { Bilateral Vim } \\
\text { Thalamus }\end{array}$ & $\mathrm{N} / \mathrm{A}$ & $\begin{array}{l}\text { Limb tremor completely } \\
\text { resolved "due to a profound } \\
\text { 'microthalamotomy' effect." } \\
\text { Decreased head tremor. } \\
\text { Worsened balance, slower } \\
\text { speech. }\end{array}$ & $\begin{array}{l}\text { DBS not turned } \\
\text { on due to } \\
\text { "microthalamotomy" } \\
\text { effect. ET dx at } \\
49 \text { yo. }\end{array}$ \\
\hline $\begin{array}{l}\text { Peters, et al. } \\
{[15]}\end{array}$ & 60 & $M$ & 112 & $\begin{array}{l}\text { Mother, } \\
\text { grandmother with } \\
\text { tremor. Two aunts } \\
\text { and one uncle with } \\
\text { tremor, gait ataxia. } \\
\text { First cousin strongly } \\
\text { affected. }\end{array}$ & $\begin{array}{l}\text { Progressive bilateral } \\
\text { postural/action tremor } \\
\text { of hands/arms, } \\
\text { postural tremor both } \\
\text { legs. Slight head } \\
\text { tremor. No rest tremor } \\
\text { in limbs. Progressive } \\
\text { gait ataxia. }\end{array}$ & $\begin{array}{l}\text { Bilateral Vim } \\
\text { Thalamus } \\
\end{array}$ & & $\begin{array}{l}\text { Marked reduction of tremor. Gait } \\
\text { ataxia persisted. }\end{array}$ & Initial dx of ET. \\
\hline $\begin{array}{l}\text { Ferrara, et } \\
\text { al. [16] }\end{array}$ & 68 & M & 106 & $\begin{array}{l}\text { Brother with tremor. } \\
\text { Daughter with } \\
\text { premature ovarian } \\
\text { failure. }\end{array}$ & $\begin{array}{l}\text { Postural and intention } \\
\text { tremor of upper } \\
\text { extremities, severely } \\
\text { limiting hand function. } \\
\text { Gait ataxia. MMSE } 25 .\end{array}$ & $\begin{array}{l}\text { Bilateral Vim } \\
\text { Thalamus }\end{array}$ & $\begin{array}{l}4 / 4 \mathrm{~V} \\
160 / 185 \mathrm{~Hz} \\
90 / 90 \mu \mathrm{sec} \\
1 / 2\end{array}$ & $\begin{array}{l}\text { Moderate to marked tremor } \\
\text { suppression. Speech and gait } \\
\text { gradually worsened with no effect } \\
\text { of DBS deactivation for } 18 \text { hours. } \\
\text { Cognition continued to decline } \\
\text { (MMSE 22). }\end{array}$ & \\
\hline $\begin{array}{l}\text { Xie, et al. } \\
{[17]}\end{array}$ & 65 & M & 75 & $\begin{array}{l}\text { Brother with tremor. } \\
\text { Daughters with } \\
\text { FMR1 premutation } \\
\text { but asymptomatic. } \\
\end{array}$ & $\begin{array}{l}\text { Severe postural, } \\
\text { kinetic, intention } \\
\text { tremors of upper } \\
\text { extremities (worse on } \\
\text { R). Mild resting tremor } \\
\text { of hands, jaw, tongue, } \\
\text { neck, moderate vocal } \\
\text { tremor. Broad gait with } \\
\text { difficulty in tandem. }\end{array}$ & $\begin{array}{l}\text { Unilateral } \\
\text { L Vim } \\
\text { Thalamus } \\
\end{array}$ & $\begin{array}{l}2.6 \mathrm{~V} \\
185 \mathrm{~Hz} \\
60 \mu \mathrm{sec} \\
1-\end{array}$ & $\begin{array}{l}\text { Significant improvement of } \\
\text { tremors. Improvements in daily } \\
\text { living function. No decline in gait, } \\
\text { speech, or cognition. }\end{array}$ & \\
\hline $\begin{array}{l}\text { Senova, et } \\
\text { al. [18] }\end{array}$ & 61 & N/A & 95 & $\begin{array}{l}\text { Sister and maternal } \\
\text { aunt with Tremor; } \\
\text { two nephews with } \\
\text { mental retardation. }\end{array}$ & $\begin{array}{l}\text { Postural and } \\
\text { intentional tremor } \\
\text { in superior limbs, } \\
\text { dominant in L, mainly } \\
\text { proximal. Cerebellar } \\
\text { ataxia present. }\end{array}$ & $\begin{array}{l}\text { Unilateral } \\
\text { R Vim } \\
\text { Thalamus }\end{array}$ & $\begin{array}{l}2.5 \mathrm{~V} \\
130 \mathrm{~Hz} \\
60 \mu \mathrm{sec} \\
0-\end{array}$ & $\begin{array}{l}\text { Tremor reduced. Ataxia SARA } \\
\text { score } 30.2 \% \text { improvement at } \\
6 \text {-month follow-up. Cognition and } \\
\text { speech not affected. }\end{array}$ & \\
\hline
\end{tabular}

Table 2: Summary of the 7 FXTAS-DBS cases reported in literature.

\section{Case 3}

Case 3 is a 70 year-old male premutation carrier with a CGG repeat of 85 . He completed 10 years of education (unfinished high school) and worked in general maintenance. His early history was uneventful except for severe headaches that he experienced from adolescence, often combined with disorientation to time and place, but they subsided when he reached adulthood. At the age of 30 he started having occasional lightheadedness, and at the age of 40 he started having resting and action tremor in both arms, more prominent on the right side. The tremor spread to involve his head and eventually his trunk and lower limbs. His past medical history also included coronary artery disease resulting in a triple bypass at the age of 46 , and arthritis of his hips and knees, with a hip replacement at the age of 65 . He was initially diagnosed with idiopathic PD and received carbidopa/levodopa
(Sinemet) treatment, with poor response. His tremor deteriorated to the degree that he could not perform any manual work, use a utensil to eat or even hold a glass of water [20].

Initial neurological examination revealed saccadic intrusions into smooth pursuit, and striking "wing-beating" tremor especially on the right arm, becoming more severe with action. Both this postural tremor and a moderate resting tremor affected his extremities with noticeable spread to his head and neck. He had moderate dysmetria on finger-tonose testing and gait ataxia with inability of tandem walking. He had extreme difficulties in writing and was unable to conduct the drawing test using his right hand. He had mild rigidity of neck, and slight to mild rigidity on arms and legs, worse on the left side. His deep tendon reflexes were normal except for being absent on left knee. His sensory testing was normal throughout. 
Neuropsychological testing, performed 12 months preoperatively, revealed deficits on MMSE (25/30) and ACE-R (73/100). The WAIS-III demonstrated a verbal IQ of 84 and a prorated FSIQ of 74 . The working memory index from the WAIS-III fell within the $55^{\text {th }}$ percentile while his perceptual organization and verbal comprehension indices both fell within the $7^{\text {th }}$ percentile. His episodic learning memory was impaired. On the WMS-III, he scored in the $3^{\text {rd }}$ percentile for auditory immediate memory, in the $1^{\text {st }}$ percentile for auditory delayed memory and in the $9^{\text {th }}$ percentile for auditory recognition-delayed memory. His processing speed was significantly slowed, falling $2.5 \mathrm{SD}$ away from the mean on the Symbol Digits Modality Test.

His MRI revealed white matter disease in periventricular regions, pons and cerebellar peduncles with a bilateral MCP sign. He also had moderate generalized cerebral and cerebellar atrophy. Because of his incapacitating tremor and poor response to treatment, he was offered a bilateral thalamic and posterior subthalamic area DBS procedure, which he underwent at age 70 years, six months after our examination.

Surgery was undertaken in Melbourne, Australia and it was carried out under local anesthetic scalp blocks and intermittent light sedation. A bicoronal incision was made and burr holes were placed 5 $\mathrm{cm}$ from the midline, over the coronal suture. The trajectory selected allowed placement of the DBS electrode through the Vim nucleus of the thalamus, and into the posterior subthalamic area. A single trajectory was utilized on each side with microelectrode recording and macrostimulation. Tremor cells were encountered on the right-hand side. Excellent tremor suppression was observed with macrostimulation bilaterally. The stimulation parameters were set at an amplitude range of 2.0-3.8 mA, frequency of $130 \mathrm{~Hz}$, and pulse width of $90 \mathrm{~Hz}$. Sensory side effects were encountered that were transient. A Saint Jude electrode was implanted at target on each side and the distal ends buried beneath the scalp.

The second stage procedure was performed under general anesthesia. An ANS Libra XP IPG was implanted without complication. Electrode positioning was confirmed with post-operative CT, merged with his pre-operative MRI.

Case 3 was reviewed 7 months postoperatively. He was continued on his Sinemet treatment after the surgery. DBS had produced a dramatic improvement in his tremor but there had been deterioration in his gait. $\mathrm{He}$ is unable to walk unaided and is now confined to a wheelchair. His speech deteriorated and occasionally he is unable to talk. He has also become incontinent and his memory deteriorated such that he has to be helped with his daily schedule, including taking his medications. $\mathrm{He}$ was admitted to the local hospital several weeks after the procedure because of his inability to walk and frequent falls, where he spent 3 weeks without significant improvement (Table 2).

\section{Discussion}

All three cases described had a typical course of FXTAS associated with severe action or intention tremors with "wing beating" quality in case 3. All three demonstrated dramatic improvement in their tremors but only case 1 had some sustained improvement in his ataxia. Case 3 had significant deterioration in his ataxia after surgery leading to the need for a wheelchair. However, he was also the most affected before the surgery with significant cognitive deficits that the first two cases did not have. There was also a worsening of speech in two of the cases.

Vim thalamus is an integrative relay of somatosensory information en route to post-central cortex. Vim neurons receive primary inputs from cerebellum and project to primary motor cortex. Neurons immediately posterior to the Vim (and within range of DBS stimulation) receive "deep" somatosensory input from the medial lemniscus. This part of the thalamus plays an important role in sensorimotor coordination, and speech and bipedal locomotion both require a good deal of sensorimotor coordination. Destructive lesions of Vim are very effective at reducing tremor, but have also produced a high incidence of balance problems and dysarthria. The postoperative flexibility to "program around" such side effects with DBS was thus enthusiastically received by neurosurgeons as a substitute for thalamotomy lesions [21]. Even a patient with a relatively uncomplicated diagnosis of essential tremor is likely to encounter side effects of dysphagia, dysarthria, gait/balance problems and fine motor discoordination during a DBS programming session. The clinical challenge is to maximize the tremor control while minimizing such side effects [22].

In the case of a patient with FXTAS, there may be a very low threshold for exacerbation by Vim DBS of gait ataxia or other motor symptoms typical of the disorder. Previous reports in the literature have documented a worsening or lack of improvement of ataxia in two cases of FXTAS after bilateral Vim thalamic DBS (Table 2) [14,15]. However, two cases of unilateral stimulation have yielded tremor improvement with no decline in speech and gait in one case [17] and with an improvement in ataxia without aggravation of other neurological deficits in the other case [18]. It is interesting in our small series that one patient showed an improvement in ataxia with Vim stimulation, while one showed a deterioration. The effect of Vim stimulation on ataxia may in fact be biphasic, with increasing amplitude producing an initial improvement, followed by deterioration to below non-DBS baseline at higher voltages [23]. Because disruption of the posterior column/ medial lemniscus somatosensory fibers produces ataxia, it is tempting to speculate that ataxia with increasing amplitude Vim DBS may be caused by recruitment and disruption of somatosensory neurons in the ventral posterolateral nucleus of the thalamus with medial lemniscal afferents. The "typical" trajectory of a Vim DBS electrode traverses the Vim from superior/anterior to inferior/posterior, and paresthesias are usually produced by stimulation of deeper contacts at levels well within the range of therapeutic values. These paresthesias are presumed to be caused by recruitment of "lemniscal" somatosensory neurons posterior to the Vim. This would suggest that in the FXTAS population, programming of Vim DBS should include gait assessment not only on and off stimulation, but at intermediate levels as well. Because dysphagia is a common correlate of dysarthria, and because aspiration pneumonia is a potentially life-threatening event, it may be important to explicitly evaluate swallowing if speech problems arise as a side effect of DBS.

The general course of FXTAS is progressive deterioration, although the progression is variable and some patients may be stable for years or even decades with only a mild tremor throughout their course. On the other hand, the more severe cases with FXTAS will suffer more severe tremors but will also be more vulnerable to the negative effects of surgery. Implantation of DBS electrodes occurs under local anesthesia with the patient awake. The surgery takes at least several hours, and is quite stressful. Any neurologically compromised patient may show exacerbation of symptoms under stress, but patients with FXTAS may be especially vulnerable. Neurons with the premutation die more easily with stress in culture compared to control neurons [24], and there is progressive deterioration of mitochondrial function in FXTAS [25]. For those with late stage FXTAS, cognitive deficits, severe autonomic dysfunction or severe ataxia may provide an unacceptable risk of significant complications or worsening of FXTAS with DBS surgery.

Vim DBS can have a dramatic effect on controlling tremor in 
Citation: Hagerman RJ, Pak JS, Ortigas M, Olichney J, Frysinger R, et al. (2012) Case Series: Deep Brain Stimulation in Patients with FXTAS. Brain Disord Ther 1:104. doi:10.4172/2168-975X.1000104

FXTAS as demonstrated in these cases. DBS can be an important treatment modality for cases of FXTAS in which tremor is a debilitating symptom in the absence of features which would provide unacceptable surgical risk or limit the degree of clinical benefit provided by tremor reduction. Although the three cases reported here responded to DBS differently with difference in improvement on tremor and ataxia noted, we believe this variation only reflects the heterogeneity of FXTAS clinical presentation in response to DBS stimulation, thus inviting additional investigation.

\section{Competing Interests}

Randi Hagerman has received funding from Novartis, Roche, Seaside Therapeutics, Forest and Curemark to carry out treatment studies in fragile $X$ syndrome and autism.

\section{Funding}

This work was supported by National Institute of Health grants HD036071 and HD02274; Neurotherapeutic Research Institute (NTRI) grants DE019583, and DA024854; National Institute on Aging grants AG032119 and AG032115 MH078041; National Center for Research Resources UL1 RR024146; support from the Health and Human Services Administration of Developmental Disabilities grant 90DD05969.

\section{Reference}

1. Hagerman RJ, Leehey M, Heinrichs W, Tassone F, Wilson R, et al. (2001) Intention tremor, parkinsonism, and generalized brain atrophy in male carriers of fragile X. Neurology 57: 127-130.

2. Tassone F, Hagerman RJ, Taylor AK, Gane LW, Godfrey TE, et al. (2000) Elevated levels of FMR1 mRNA in carrier males: a new mechanism of involvement in the fragile-X syndrome. Am J Hum Genet 66: 6-15.

3. Jacquemont S, Hagerman RJ, Leehey MA, Hall DA, Levine RA, et al. (2004) Penetrance of the fragile $\mathrm{X}$-associated tremor/ataxia syndrome in a premutation carrier population. JAMA 291: 460-469.

4. Coffey SM, Cook K, Tartaglia N, Tassone F, Nguyen DV, et al. (2008) Expanded clinical phenotype of women with the FMR1 premutation. Am J Med Genet A 146A: 1009-1016.

5. Rodriguez-Revenga L, Madrigal I, Pagonabarraga J, Xunclà M, Badenas C, et al. (2009) Penetrance of FMR1 premutation associated pathologies in fragile $X$ syndrome families. Eur J Hum Genet 17: 1359-1362.

6. Leehey MA, Berry-Kravis E, Min SJ, Hall DA, Rice CD, et al. (2007) Progression of tremor and ataxia in male carriers of the FMR1 premutation. Mov Disord 22 203-206

7. Berry-Kravis E, Abrams L, Coffey SM, Hall DA, Greco C, et al. (2007) Fragile $\mathrm{X}$-associated tremor/ataxia syndrome: clinical features, genetics, and testing guidelines. Mov Disord 22: 2018-2030.

8. Grigsby J, Brega AG, Engle K, Leehey MA, Hagerman RJ, et al. (2008) Cognitive profile of fragile $X$ premutation carriers with and without fragile $\mathrm{X}$-associated tremor/ataxia syndrome. Neuropsychology 22: 48-60.

9. Adams JS, Adams PE, Nguyen D, Brunberg JA, Tassone F, et al. (2007) Volumetric brain changes in females with fragile $\mathrm{X}$-associated tremor/ataxia syndrome (FXTAS). Neurology 69: 851-859.

10. Greco CM, Berman RF, Martin RM, Tassone F, Schwartz PH, et al. (2006) Neuropathology of fragile X-associated tremor/ataxia syndrome (FXTAS). Brain 129: 243-255.

11. Gokden M, Al-Hinti JT, Harik SI (2009) Peripheral nervous system pathology in fragile X tremor/ataxia syndrome (FXTAS). Neuropathology 29: 280-284.

12. Greco CM, Soontrapornchai K, Wirojanan J, Gould JE, Hagerman PJ, et al. (2007) Testicular and pituitary inclusion formation in fragile $X$ associated tremor/ataxia syndrome. J Urol 177: 1434-1437.

13. Hall DA, Berry-Kravis E, Jacquemont S, Rice CD, Cogswell J, et al. (2005) Initial diagnoses given to persons with the fragile $X$ associated tremor-ataxia syndrome (FXTAS). Neurology 65: 299-301.

14. Leehey MA, Munhoz RP, Lang AE, Brunberg JA, Grigsby J, et al. (2003) The fragile $X$ premutation presenting as essential tremor. Arch Neurol 60: 117-121.
15. Peters N, Kamm C, Asmus F, Holinski-Feder E, Kraft E, et al. (2006) Intrafamilial variability in fragile X-associated tremor/ataxia syndrome. Mov Disord 21: 98102.

16. Ferrara JM, Adam AR, Ondo WG (2009) Treatment of fragile-X-associated tremor/ataxia syndrome with deep brain stimulation. Mov Disord 24: 149-151.

17. Xie T, Goodman R, Browner N, Haberfeld E, Winfield L, et al. (2012) Treatment of fragile $\mathrm{X}$-associated tremor/ataxia syndrome with unilateral deep brain stimulation. Mov Disord 27: 799-800.

18. Senova S, Jarraya B, Iwamuro H, Tani N, Ouerchefani N, et al. (2012) Unilatera thalamic stimulation safely improved fragile $X$-associated tremor ataxia: A case report. Mov Disord 27: 797-799.

19. Rodriguez-Oroz MC, Obeso JA, Lang AE, Houeto JL, Pollak P, et al. (2005) Bilateral deep brain stimulation in Parkinson's disease: a multicentre study with 4 years follow-up. Brain 128: 2240-2249.

20. Loesch DZ, Khaniani MS, Slater HR, Rubio JP, Bui QM, et al. (2009) Small CGG repeat expansion alleles of FMR1 gene are associated with parkinsonism. Clin Genet 76: 471-476.

21. Benabid AL, Pollak P, Gervason C, Hoffmann D, Gao DM, et al. (1991) Long term suppression of tremor by chronic stimulation of the ventral intermediate thalamic nucleus. Lancet 337: 403-406.

22. Aguilar D, Sigford KE, Soontarapornchai K, Nguyen DV, Adams PE, et al. (2008) A quantitative assessment of tremor and ataxia in FMR1 premutation carriers using CATSYS. Am J Med Genet A 146A: 629-635.

23. Fasano A, Herzog J, Raethjen J, Rose FE, Muthuraman M, et al. (2010) Gait ataxia in essential tremor is differentially modulated by thalamic stimulation. Brain 133: 3635-3648.

24. Chen Y, Tassone F, Berman RF, Hagerman PJ, Hagerman RJ, et al. (2010) Murine hippocampal neurons expressing Fmr1 gene premutations show early developmental deficits and late degeneration. Hum Mol Genet 19: 196-208.

25. Ross-Inta C, Omanska-Klusek A, Wong S, Barrow C, Garcia-Arocena D, et al. (2010) Evidence of mitochondrial dysfunction in fragile X-associated tremor/ ataxia syndrome. Biochem J 429: 545-552. 